\title{
VALIDASI METODE FOTODEGRADASI CONGO RED TERKATALIS ZnO/ZEOLIT Y SECARA SPEKTROFOTOMETRI UV-VIS
}

\author{
Regina Gita Riani Dio ${ }^{1}$, Syaiful Bahri ${ }^{2}$, Agung Abadi Kiswandono ${ }^{2}$, R. Supriyanto ${ }^{2 *}$ \\ ${ }^{1,2}$ Jurusan Kimia, FMIPA Universitas Lampung
}

\author{
r.supriyanto@gmail.com
}

\begin{abstract}
ABSTRAK
Industri tekstil memproduksi pakaian dengan berbagai macam warna. Dalam proses

$\underline{\text { Artikel Info }}$

Diterima

tanggal

10.02.2021

Disetujui

publikasi

tanggal

13.05.2021

Kata kunci:

Congo Red,

Spektrofotometer

UV-Vis, validasi,

Fotodegradasi,

$\mathrm{ZnO/Zeolit} \mathrm{Y}$ pewarnaan tekstil, sebagian besar zat warna yang digunakan akan terbuang sebagai limbah. Congo red merupakan salah satu zat warna tekstil yang banyak digunakan. Namun keberadaan zat warna congo red dalam lingkungan perairan dapat merusak berbagai spesies makhluk hidup karena sifat zat warna congo red yang mempunyai toksisitas cukup tinggi. Metode alternatif yang sekarang sedang dikembangkan oleh peneliti untuk mendegradasi limbah adalah metode fotodegradasi. penelitian tentang validasi metode congo red terkatalis $\mathrm{ZnO} / \mathrm{Zeolit} \mathrm{Y}$ secara spektrofotometri UV-Vis, validasi metode bertujuan untuk mendapatkan panjang gelombang optimum, $\mathrm{pH}$ optimum, waktu optimum. Pada penelitian ini dilakukan validasi metode congo red terkatalis $\mathrm{ZnO} / \mathrm{Zeolit} \mathrm{Y}$ secara spektrofotometri UV-Vis dengan menentukan linieritas kurva kalibrasi larutan congo red, menentukan limit deteksi (LoD) dan limit kuantifikasi (LoQ), menentukan presisi, menentukan akurasi, dan pengaruh penggunaan katalis $\mathrm{ZnO} /$ Zeolit Y. Panjang gelombang optimum larutan pewarna Congo Red $498 \mathrm{~nm}$ dengan $\mathrm{pH}$ optimum pada $\mathrm{pH}$ 5, degradasi warna Congo Red tanpa katalis terjadi pada waktu optimum 120 menit dengan persentase degradasi sebesar 21,68\%, penambahan katalis zeolit Y $0,6 \mathrm{mg}$ dapat menurunkan intensitas warna Congo Red sebesar 63,30\%, sedangkan penambahkan 0,6 mg ZnO/Zeolit Y dapat menurunkan intensitas warna Congo Red sebesar 78,01\%.
\end{abstract}

\begin{abstract}
The textile industry produces clothing in a variety of colors. In the textile dyeing process, most of the dyes used will be wasted as waste. Congo red is one of the most widely used textile dyes. However, the presence of congo red dye in the aquatic environment can damage various species of living things because of the nature of the congo red dye which has a fairly high toxicity. An alternative method currently being developed by researchers to degrade waste is the photodegradation method. research on the validation of the $\mathrm{ZnO} /$ Zeolite $\mathrm{Y}$-catalyzed congo red method by UV-Vis spectrophotometry, method validation aims to obtain the optimum wavelength, optimum $\mathrm{pH}$, optimum time. In this study, validation of the $\mathrm{ZnO} /$ Zeolite $\mathrm{Y}$-catalyzed congo red method was carried out by UVVis spectrophotometry by determining the linearity of the calibration curve of the congo red solution, determining the detection limit (LoD) and quantification limit (LoQ), determining precision, determining accuracy, and the effect of using a catalyst. ZnO/Zeolite Y. The optimum wavelength of Congo Red dye solution is $498 \mathrm{~nm}$ with optimum $\mathrm{pH}$ at $\mathrm{pH} 5$, Congo Red color degradation without a catalyst occurs at an optimum time of 120 minutes with a degradation percentage of $21.68 \%$, the addition of zeolite $\mathrm{Y}$ catalyst is $0.6 \mathrm{mg}$ can reduce the color intensity of Congo Red by $63.30 \%$, while the addition of $0.6 \mathrm{mg} \mathrm{ZnO/Zeolite} \mathrm{Y}$ can reduce the color intensity of Congo Red by $78.01 \%$.
\end{abstract}

http://dx.doi.org/10.23960/aec.v6.i2.2021.p134-144

Anal.Environ.Chem. 


\section{PENDAHULUAN}

Perkembangan teknologi industri menyebabkan pencemaran lingkungan, salah satunya industri tekstil. Industri tekstil memproduksi pakaian dengan berbagai macam warna. Dalam proses pewarnaan tekstil, sebagian besar zat warna yang digunakan akan terbuang sebagai limbah. Congo red merupakan salah satu zat warna tekstil yang banyak digunakan. Congo red merupakan zat warna azo yang dapat terikat kuat pada kain, sehingga tidak mudah luntur, memberikan warna yang baik dan tidak mudah rusak oleh perlakuan kimia (Blackburn and Burkinshaw, 2002). Namun keberadaan zat warna congo red dalam lingkungan perairan dapat merusak berbagai spesies makhluk hidup karena sifat zat warna congo red yang mempunyai toksisitas cukup tinggi. Congo red yang terakumulasi dalam tubuh dapat menyebabkan gangguan fungsi hati, ginjal,dan syaraf (Bensalah et al., 2009; Wróbel et al., 2001; Dawood et al., 2014; Wardhana, 2004). Mengingat efek yang ditimbulkan oleh zat warna tekstil Congo Red terhadap lingkungan dan makhluk hidup di dalamnya, perlu dilakukan berbagai upaya untuk meminimalisir limbah zat warna tersebut sebelum dibuang ke dalam system perairan.

Banyak metode digunakan untuk pengolahan limbah zat warna ini seperti elektrokoagulasi, filtrasi kimia, serta adsorpsi. Namun, metode-metode tersebut dinilai kurang efektif karena menggunakan biaya operasional yang besar dan diperlukan waktu yang lama sertas zat warna tekstil yang diadsorpsi masih terakumulasi di dalam adsorben yang pada suatu saat nanti akan menimbulkan persoalan baru. Metode alternatif yang sekarang sedang dikembangkan oleh peneliti untuk mendegradasi limbah adalah metode fotodegradasi. Fotodegradasi adalah suatu proses penguraian senyawa organik menjadi senyawa yang lebih sederhana dengan menggunakan bantuan energi foton dan radiasi sinar UV. Prinsipnya menggunakan fotokatalis yang berasal dari bahan semikonduktor, seperti $\mathrm{TiO}_{2}, \mathrm{ZnO}, \mathrm{Fe}_{2} \mathrm{O}_{3}, \mathrm{CdS}$, dan sebagainya (Sakthivel et al., 2003).

Semikonduktor $\mathrm{ZnO}$ memiliki keuntungan dibandingkan dengan $\mathrm{TiO}_{2}$ karena dia mampu menyerap spektrum matahari dan kuantum cahaya lebih banyak dibandingkan dengan $\mathrm{TiO}_{2}$. Material $\mathrm{ZnO}$ memiliki jarak celah pita yang lebih besar $(3,4 \mathrm{eV})$ daripada $\mathrm{TiO}_{2}$ sebesar $3,2 \mathrm{eV}$ (Singh, 2009). Metode fotodegradasi akan meyebabkan zat warna terurai menjadi komponenkomponen yang lebih sederhana dan lebih aman untuk lingkungan. 
Dari uraian yang telah dipaparkan diatas maka dilakukan penelitian tentang validasi metode congo red terkatalis $\mathrm{ZnO} /$ Zeolit $\mathrm{Y}$ secara spektrofotometri UV-Vis, validasi metode bertujuan untuk mendapatkan panjang gelombang optimum, $\mathrm{pH}$ optimum, waktu optimum. Pada penelitian ini dilakukan validasi metode congo red terkatalis $\mathrm{ZnO} /$ Zeolit $\mathrm{Y}$ secara spektrofotometri UV-Vis dengan menentukan linieritas kurva kalibrasi larutan congo red, menentukan limit deteksi (LoD) dan limit kuantifikasi (LoQ), menentukan presisi, menentukan akurasi, dan pengaruh penggunaan katalis $\mathrm{ZnO} /$ Zeolit $\mathrm{Y}$. Hasil yang diharapkan mengetahui pengaruh katalis $\mathrm{ZnO}$ terhadap intensitas warna larutan.

\section{METODE}

\section{Alat dan Bahan}

Alat-alat yang akan digunakan dalam penelitian ini adalah alat-alat gelas dan alat pendukung lainnya, Spektrofotometer UV-Vis, pH meter, Scanning Electron Microscopy (SEM), XRD, reaktor fotodegradasi sinar tampak, pengaduk magnit, lux meter, tanur, dan neraca analitik.Bahan-bahan yang digunakan dalam penelitian ini adalah pewarna tekstil Congo Red, zeolit-Y, $\mathrm{ZnSO}_{4} 2 \mathrm{M}, \mathrm{ZnO} / \mathrm{Zeolit} \mathrm{Y}, \mathrm{H}_{2} \mathrm{SO}_{4}$ 0,01 M, NaOH 0,01 M dan akuades.

\section{Prosedur}

\section{ValidasiMetode}

\section{a. Pembuatan Larutan Baku Pewarna Congo Red}

- Ditimbang 1,0 gram pewarna Congo Red, dilarutkan menggunakan akuades dalam labu takar hingga tanda batas $1000 \mathrm{~mL}$. Diperoleh larutan pewarna tekstil Congo Red $1000 \mathrm{ppm}$.

- Diencerkan menjadi 50 ppm.

\section{b. Penentuan Linieritas Kurva Kalibrasi Larutan Congo Red}

Dibuat larutan Congo Red dengan konsentrasi yang berbeda yaitu 8 ppm, 12 ppm, 16 ppm, 20 ppm, dan 24 ppm. Masing-masing larutan tersebut diukur absorbansinya dengan Spektrofotometer UV-Vis. Absorbansi yang diperoleh dibuat persamaan linier hubungan antara konsentrasi dengan absorbansi. Nilai r yang diperoleh menggambarkan liniearitas. 


\section{c. Penentuan Limit Deteksi (LoD) dan Limit Kuantifikasi (LoQ)}

Penentuan Limit Deteksi (LoD) dan Limit Kuantifikasi (LoQ) diperoleh dari pengukuran pewarna tekstil Congo Red yang diambil dari konsentrasi yang paling rendah dari penentuan linieritas $(8 \mathrm{ppm})$ kemudian ditambahkan akuades dengan perbandingan $2 \mathrm{~mL}$ sampel dengan 4 $\mathrm{mL}$ akuades (1:2). Larutan tersebut diukur absorbansinya sebanyak 7 kali pengulangan.

\section{d. Penentuan Presisi}

Penentuan presisi dilakukan dengan mengukur pewarna tekstil Congo Red yang di ambil dari konsentrasi 16 ppm $1 \mathrm{ml}$ kemudian diencerkan dengan akuades sebanyak $10 \mathrm{~mL}$.Sampel tersebut diukur dengan 7 kali pengulangan. Nilai absorbansi yang telah diperoleh ditentukan nilai konsentrasi, simpangan baku (SD) serta nilai relatif standar deviasi (RSD). Metode dengan presisi yang baik ditunjukkan dengan perolehan relatif standar deviasi (RSD) $<5 \%$.

\section{e. Penentuan Akurasi}

Penentuan akurasi dilakukan dengan cara menambahkan larutan yang diukur pada penentuan presisi sebanyak $1 \mathrm{~mL}$ dengan larutan yang diketahui konsentrasinya ( $8 \mathrm{ppm}$ ) sebanyak $9 \mathrm{~mL}$. Kemudian campuran diukur absorbansinya dengan 7 kali pengulangan.Nilai absorbansi yang diperoleh dihitung nilai recovery nya.

\section{Pengaruh Penggunaan Katalis $\mathrm{ZnO} /$ Zeolit $\mathrm{Y}$}

Dengan menggunakan kuat cahaya, waktu dan $\mathrm{pH}$ optimum.100 mL larutan pewarna

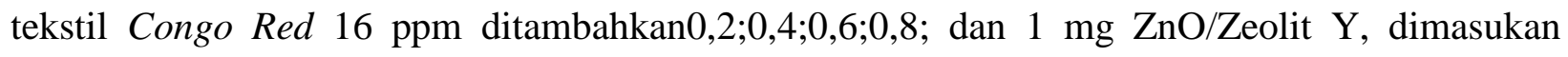
kedalam reaktor fotoreduksi. Kemudian larutanhasil fotodegradasi dianalisis menggunakan spektrofotometer UV-Vis pada panjang gelombang $498 \mathrm{~nm}$.

\section{HASIL DAN PEMBAHASAN}

\section{A. Penyiapan Katalis Zeolit-Y-ZnO}

Zeolit-Y-ZnO dibuat dengan metode impregnasi, dengan cara melarutan $\mathrm{ZnSO}_{4}$ sebanyak 3,22 gram dalam Erlenmeyer berisi $100 \mathrm{ml}$ aquabides dan 5,0 gam zeolit-Y kemudian dilakukan pemanasan serta pengadukan selama 2 jam hal ini supaya ion $\mathrm{Zn}^{2+}$ dapat masuk ke dalam poripori zeolit, lalu ditambahkan $\mathrm{NaOH}$ untuk membuat kondisi larutan menjadi basa. Dilanjutkan dengan pemanasan serta pengadukan selama 2 jam. Kemudian dilakukan pengeringan 
menggunakan oven selama 24 jam pada suhu $80^{\circ} \mathrm{C}$ agar zeolit-Y-ZnO terpisah dari larutannya. Hasil yang diperoleh kemudian dihaluskan hingga menghasilkan serbuk dandi kalsinasi selama 2 jam (setelah suhu tanur stabil) pada suhu $600^{\circ} \mathrm{C}$ proses kalsinasi sendiri dilakukan agar senyawa organik yang terdapat pada rongga terurai.

\section{B. Validasi Metode}

\section{Linieritas}

Analisis menggunakan instrumentasi disebut juga dengan metode analisis relatif karena analit yang akan ditentukan dibandingkan dengan larutan yang sudah diketahui secara pasti rumus molekulnya dan konsentrasinya, sedangkan analisis absolut dikenal dengan metode analisis klasik atau absolut seperti analisis volumetri dan gravimetri.

Uji linieritas ini dilakukan dengan cara membuat kurva kalibrasi standar dengan variasi konsentrasi dari 8,0;12,0;16,0;20,0;24,0 ppm, dianalisi pada panjang optimum $498 \mathrm{~nm}$ menggunakan Spektrofotometer UV-Vis, dari kurva kalibrasi yang diperoleh persamaan garis lurus dan koefisien korelasi yang digunakan untuk mengetahui hubungan antara konsentrasi larutan standar dengan nilai absorbansi yang dihasilkan. Parameter yang digunakan untuk menunjukkan hubungan yang linier adalah koefisien kolerasi (r) pada analisis regresi linier $\mathrm{Y}=\mathrm{a}$ + bX. Kurva linieritas ditunjukkan pada Gambar 1.

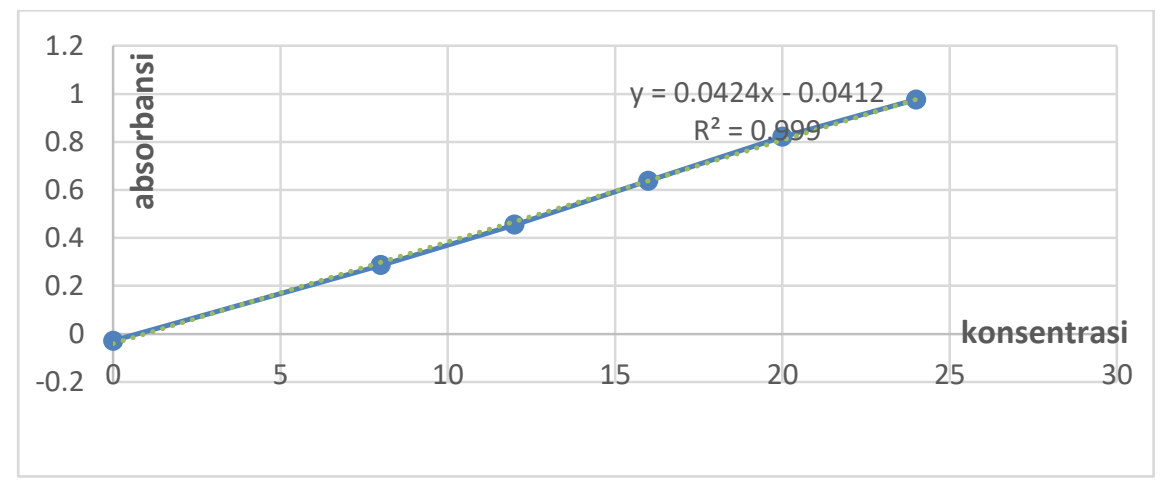

\section{Gambar 1. Kurva Kelinieran (Kurva Kalibrasi Standar)}

Berdasarkan Gambar 1 persamaan regresi linier yang diperoleh dari kurva regresi larutan standar Congo Red adalah Y = (0,0424x - 0,0412) dengan koefisien korelasi sebesar 0,999. Nilai koefisien korelasi yang didapat mendekati satu dan dikatakan baik karena memenuhi persyaratan 
yaitu $0,999<\mathrm{r}^{2}<1$ menunjukkan hubungan yang linier antara konsentrasi larutan standar dengan absorbansi yang dihasilkan berdasarkan hukum lambert beer yaitu $A=$ eb C. Sesuai dengan syarat keberterimaan yaitu nilai koefisien korelasi hasil uji linieritas adalah > 0,99 (AOAC, 2002) dan >0,9970 ( Chan et al., 2004).

\section{Penentuan Limit Deteksi (LoD) dan Limit Kuantifikasi (LoQ)}

Batas deteksi (LoD) dan batas kuantifikasi (LoQ) merupakan uji sensitivitas metode. Batas deteksi merupakan jumlah konsentrasi terkecil analit dalam sampel yang dapat dideteksi yang masih memberikan respon signifikan dibandingkan dengan blanko.Batas kuantifikasi merupakan kuantitas terkecil analit dalam sampel yang masih dapat memenuhi kriteria cermat dan seksama.

Pada penelitian ini, sampel dengan konsentrasi terkecil akan diukur absorbansinya dengan menggunakan instrumen spektrofotometer UV-Vis. Batas deteksi ditentukan bertujuan untuk mengetahui absorbansi dari sampel dengan konsentrasi yang paling kecil tersebut yakni 8 ppm. Berdasarkan hasil perhitungan diperoleh nilai LoD dan LoQ untuk analisis sampel dapat dilihat pada Tabel 1.

Tabel 1. Pengukuran dan Perhitungan Nilai LoD dan LoQ

\begin{tabular}{ccc}
\hline Pengulangan & abs (y) & $\begin{array}{c}\text { konsentrasi terukur } \\
(\mathbf{x})\end{array}$ \\
\hline 1 & 0,078 & 2,80976 \\
2 & 0,078 & 2,80976 \\
3 & 0,078 & 2,80976 \\
4 & 0,077 & 2,78619 \\
5 & 0,077 & 2,78619 \\
6 & 0,077 & 2,78619 \\
7 & 0,077 & 2,78619 \\
\hline Total & 0,542 & 19,57407 \\
\hline Rata-rata & 0,07742 & 2,79629 \\
\hline SD & & \\
\hline 0,000534 & 0,001603 & $\mathbf{1 0 S D}$ \\
\hline
\end{tabular}

Berdasarkan Tabel 1 nilai LoD 0,03779 yang didapat dalam penelitian ini mampu memberikan respon untuk analisis pewarna tekstil Congo Red dengan jumlah yang kecil. Begitu 
pula dengan nilai LoQ 0,12598 yang mampu memberikan respon dengan nilai akurasidan presisi yang dapat diterima dalam analisis.

\section{Uji Presisi}

Pada penelitian ini, penentuan nilai presisi ditentukan dengan mengukur satu sampel air yang mengandung pewarna tekstil Congo Red. Kemudian diukur dan dilakukan pengulangan sebanyak 7 kali. Berikut hasil pengukuran sampel air yang mengandung pewarna tekstil pada Tabel 2.

\section{Tabel 2. Pengamatan dan Perhitungan Uji Presisi}

\begin{tabular}{ccc}
\hline Pengulangan & abs $(\mathbf{y})$ & konsentrasi $(\mathbf{x})$ \\
\hline 1 & 0,053 & 2,22053 \\
2 & 0,052 & 2,19696 \\
3 & 0,053 & 2,22053 \\
4 & 0,052 & 2,19696 \\
5 & 0,052 & 2,19696 \\
6 & 0,051 & 2,17340 \\
7 & 0,052 & 2,19696 \\
\hline Total & 0,365 & 15,40235 \\
\hline Rata-rata & 0,052143 & 2,20033 \\
\hline SD & \% RSD \\
\hline 0,00069 & 1,32 \\
\hline
\end{tabular}

Berdasarkan tabel 2. \%RSD dan CV yang diperoleh adalah 1,32\%, sehingga dapat dikatakan bahwa perolehan \%RSD pada hasil penelitian ini adalah baik. Menurut Yuwono dan Indrayanto (2005) nilai RSD dikatakan baik apabila < 2,7\%.Menurut Ahuja dan Dong (2005) nilai penerimaan RSD tidak > 20\%.Menurut Harmita (2004) kriteria seksama diberikan jika metode memberikan nilai \% RSD $\leq 2 \%$.Menurut AOAC (2002) nilai RSDr < 15\%. Menurut Christian (1994) nilai RSD yang baik adalah < 5\% untuk tingkat kepercayaan 95\%.Berdasarkan nilai RSD yang didapat maka metode tergolong baik.

\section{Uji Akurasi}

Akurasi merupakan ukuran yang menunjukkan derajat kedekatan hasil analisis dengan konsentrasi analit yang sebenarnya. Akurasi dinyatakan sebagai persen perolehan kembali (recovery) standar yang ditambahkan.Nilai akurasi dihitung berdasarkan persen perolehan 
kembali (recovery).Berikut hasil pengukuran sampel air yang mengandung pewarna tekstil pada Tabel 3.

Tabel 3. Pengukuran dan Perhitungan Akurasi

\begin{tabular}{cccc}
\hline Penulangan & abs $(\mathbf{y})$ & $\begin{array}{c}\text { konsentrasi } \\
\text { terukur }(\mathbf{x})\end{array}$ & Akurasi (\%) \\
\hline 1 & 0,224 & 6,25084 & 104,181 \\
2 & 0,223 & 6,22727 & 103,788 \\
3 & 0,221 & 6,18013 & 103,002 \\
4 & 0,22 & 6,15656 & 102,609 \\
5 & 0,212 & 5,96801 & 99,467 \\
6 & 0,211 & 5,94444 & 99,074 \\
7 & 0,207 & 5,85016 & 97,502 \\
\hline Total & 1,518 & 42,57744 & 709,624 \\
\hline Rata-rata & 0,21685 & 6,08249 & 101,375 \\
\hline
\end{tabular}

Berdasarkan Tabel 3. \% Recovery yang didapat dari pengukuran adalah 101,375.Menurut AOAC pada tahun 1998, menyatakan bahwa akurasi yang baik yaitu apabila persen perolehan kembali yang didapat pada konsentrasi 0,1-10 ppm berada diantara80\% - 110\%. Sehingga pada tabel 5 akurasi pada penelitian ini dikategorikan baik.

\section{Pengaruh Penambahan Katalis ZnO/Zeolit Y Pada Larutan Congo Red}

$100 \mathrm{~mL}$ larutan pewarna tekstil Congo Red 16 ppm ditambahkan katalisZnO/Zeolit Ydengan variasi 2,$0 ; 4,0 ; 6 ; 0 ; 8,0 ; 1,0 \mathrm{mg}$, selanjutnya pada masing-masing berat katalis yang ditambahkan ke dalam larutan Congo Red dilakukan fotodegradasi selama 0 sampai 240 menit dengan rentang setiap 30 menit. Hasil analisis dan pengamatan dapat dilihat pada tabel 4 dan gambar 3 serta 4 antara waktu dan berat katalis yang ditambahkan.

Tabel 4. Pengaruh Katalis $\mathrm{ZnO} /$ Zeolit Y

\begin{tabular}{llllrlllll}
\hline $\begin{array}{l}\text { Berat } \\
(\mathrm{mg})\end{array}$ & \multicolumn{10}{c}{ Waktu (menit) } \\
\cline { 2 - 10 } & 0 & \multicolumn{1}{c}{30} & 60 & 90 & 120 & 150 & 180 & 210 & 240 \\
\hline 0,20 & 0,647 & 0,622 & 0,591 & 0,54 & 0,442 & 0,371 & 0,302 & 0,233 & 0,171 \\
0,40 & 0,644 & 0,59 & 0,532 & 0,483 & 0,394 & 0,337 & 0,281 & 0,213 & 0,152 \\
0,60 & 0,642 & 0,596 & 0,524 & 0,465 & 0,373 & 0,309 & 0,248 & 0,186 & 0,109 \\
0,80 & 0,641 & 0,596 & 0,529 & 0,467 & 0,376 & 0,311 & 0,242 & 0,179 & 0,101 \\
1,00 & 0,639 & 0,578 & 0,512 & 0,451 & 0,362 & 0,297 & 0,229 & 0,163 & 0,094 \\
\hline
\end{tabular}

Dari data yang di dapat diketahui bahwa dengan penambahan katalis $\mathrm{ZnO} /$ Zeolit Y sebanyak 0,6 mg dapat menurunkan intensitas warna dari larutan Congo Red dengan waktu penyinaran 
menggunakan lampu pijar 50 Watt dan kuat cahaya 8000 Lux, hal ini menunjukkan dengan adanya $\mathrm{ZnO}$ dalam zeolit Y mempercepat lajudegradasi warna, perubahan warna Congo Red sekitar 78,01\%. Hal itu menunjukkan bahwa penambahan $\mathrm{ZnO}$ pada zeolit-Y mempengaruhi fotoreduksi dari Congo Red. Pemilihan penambahan katalis $\mathrm{ZnO} /$ Zeolit Y sebesar 0,6 mg dalam larutan $100 \mathrm{~mL}$ konsentrasi $16 \mathrm{ppm}$ merupakan penentuan yang optimal demi efisiensi katalis yang digunakan untuk proses fotodegradasi.

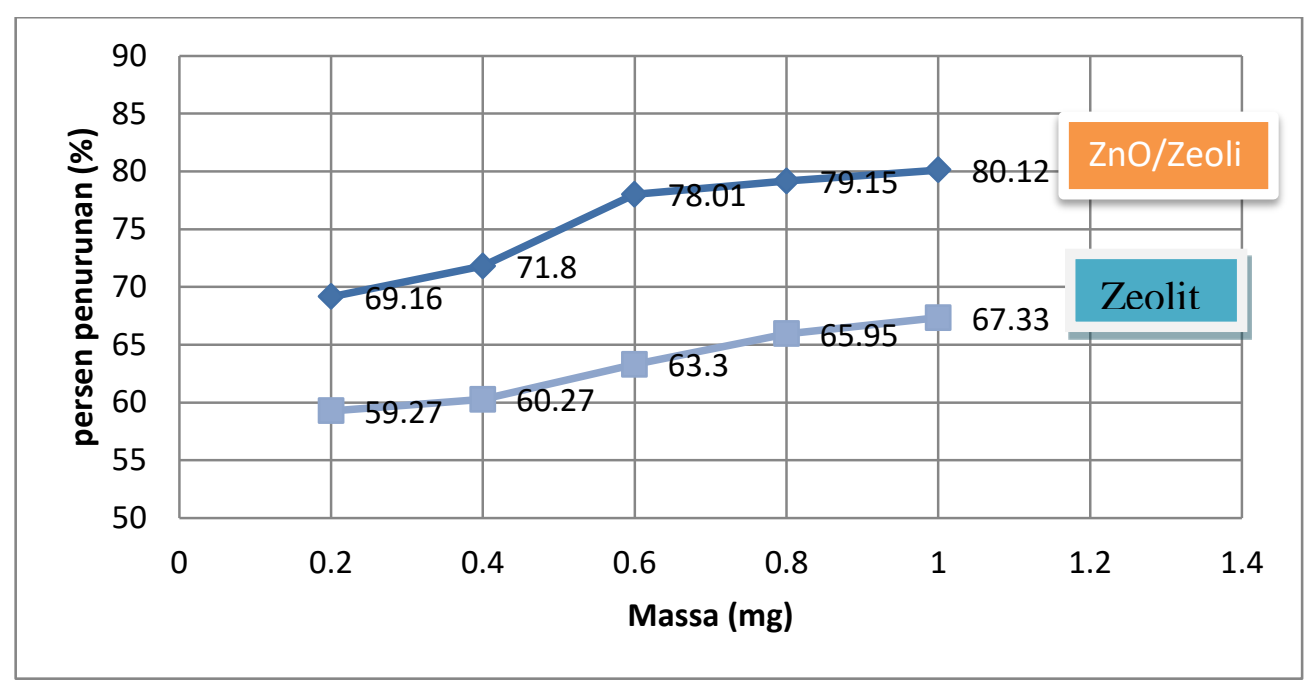

Gambar 2. Perbandingan grafik persen penurunan konsentrasi antara variasi penambahan zeolit-Y dengan penambahan zeolit-Y-ZnO

Dari gambar 2 terlihat bahwa katalis zeolit-Y-ZnO dapat meningkatkan efektifitas dari fotoreduksi disebabkan karena pada saat proses fotoreduksi energi foton yang dipancarkan membuat katalis zeolit-Y-ZnO mengalami eksitasi elektron sehingga menyebabkan adanya reaksi reduksi dan menghasilkan ion hidroksil $\left(\mathrm{OH}^{-}\right)$yang mana berikatan dengan Congo Red. Sedangkan pada penambahan zeolit-Y kelimpahan ion hidroksil $\left(\mathrm{OH}^{-}\right)$pada larutan tidak sebanyak dengan adanya penambahan katalis zeolit-Y-ZnO, selain itu adsorpsi Congo Redoleh zeolit-Y juga membantu menurunkan konsentrasi Congo Red terlarut.Hal itu mengakibatkan penambahan zeolit-Y menunjukkan penurunan konsentrasi Congo Red meningkat dibandingkan kondisi awal (tidak dilakukan penambahan katalis maupun zeolit dengan keadaan $\mathrm{pH}$ netral). Sementara itu, penelitian yang dilakukan oleh Widiantini (2013) dengan jumlah katalis sebanyak 2,29 mg hanya mampu mendegradasi larutan congo red sebanyak 1,24\%. Dari hasil penelitian yang diperoleh dengan penambahan $0,6 \mathrm{mg}$ sudah dapat mendegadasi Congo Red sebanyak 78,01 \%. Jadi penelitian ini baik dilakukan untuk mendegradasi pewarna tekstil Congo Red. 
Karakterisasi zeolit-Y-ZnO menggunakan SEM bertujuan untuk mengetahui morfologi dan bentuk partikel pada permukaan katalis.Dalam penelitian ini, analisis SEM dilakukan terhadap katalis zeolit-Y-ZnO.

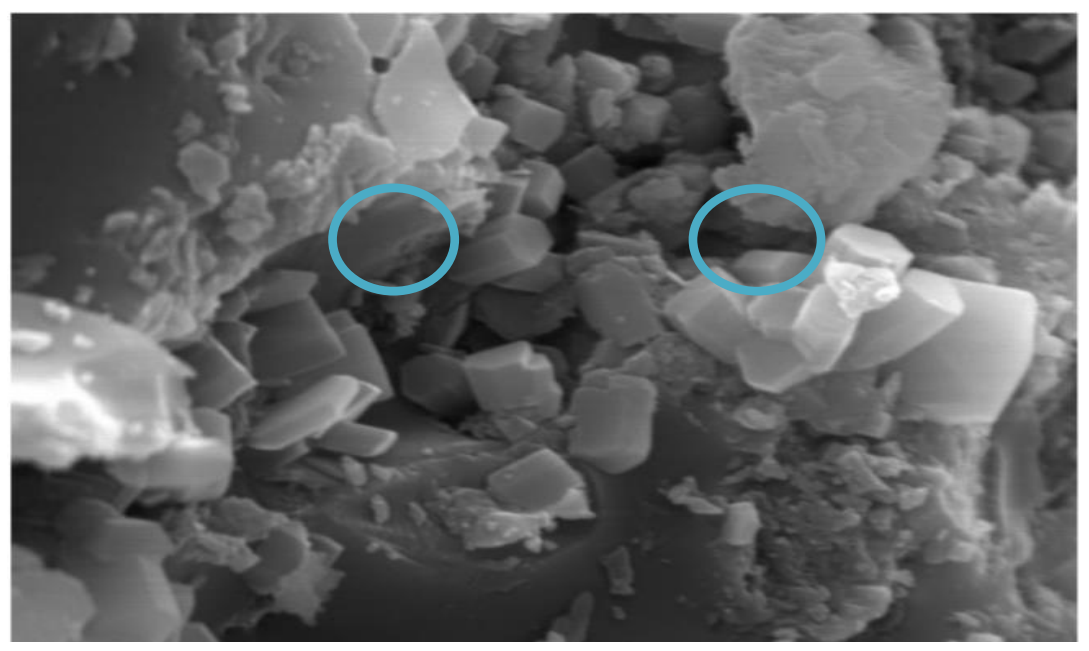

Gambar 3. Mikograf perbesaran 25000x Katalis $\mathrm{ZnO}$ /Zeolit $\mathrm{Y}$

Pada Gambar 3 dapat terlihat bahwa bentuk morfologi katalis zeolit-Y-ZnO adalah heksagonal ditunjukkan dengan struktur yang menggumpal dengan permukaan gumpalan terdapat material berukuran kecil tersebar secara acak. Gumpalan tersebut diduga sebagai material zeolit dengan ukuran 4-13 mikrometer.Sedangkan material yang tersebar secara acak di atas permukaan gumpalan diduga sebagail Zink Oksida ( $\mathrm{ZnO})$ dengan ukuran 0,31-0,35 mikrometer. Dalam analisis ini menunjukkan adanya penambahan $\mathrm{ZnO}$ dilihat dari terbentuk atau tidak situs aktif sehingga dapat menambah kinerja katalis untuk mendegradasi pewarna tekstil Congo Red.

\section{KESIMPULAN}

1. Hasil pengukuran menggunakan Spektrofotometer UV-Vis diperoleh panjang gelombang optimum Congo Red pada $498 \mathrm{~nm}$.

2. $\mathrm{pH}$ optimum yang diperoleh dari hasil fotodegradasi adalah $\mathrm{pH} 5$ dengan persen penurunan sebesar $49,22 \%$.

3. Waktu optimum yang diperoleh pada proses fotodegradasi adalah 120 menit dengan persentase sebesar $9,62 \%$. 
4. Fotodegradasi menggunakan reaktor fotoreduksi dengan penambahan zeolit-Y 0,6 mg, $\mathrm{pH} \mathrm{5,0}$ selama 120 menit menghasilkan penurunan intensitas warna larutan sebesar 63,30\%.

5. Fotodegrdasi menggunakan reaktor fotoreduksi dengan penambahan katalis $\mathrm{ZnO} / \mathrm{Zeolit}$ Y 0,6 mg, selama 120 menit, $\mathrm{pH}$ 5,0, menghasilkan penurunan intensitas larutan pewarna Congo $\operatorname{Red} 78,01 \%$.

\section{DAFTAR PUSTAKA}

Bensalah, N., M.Q. Alfaro, C.A. Martínez-Huitle, 2009, Electrochemical treatment of synthetic wastewaters containing Alphazurine A dye, Chem. Eng. J., 149 (1-3):348-352.

Blackburn, R.R. And S.M. Burkinshaw, 2002, A Greener to Cotton Deing With Excellent Wash Fastness, Green Chem., (4): 47-52.

Dawood, S., T.K. Sen, C. Phan., 2014, Synthesis and characterisation of novel-activated carbon from waste biomass pine cone and its application in the removal of Congo red dye from aqueous solution by adsorption, Water Air Soil Pollut., 225 (1):1818.

Sakthivel, S., Neppolian, B., Shankar, V., Arabindoo, B., Palanichamy, M. dan Murugesen, V., 2003, Solar Photocatalytic Degradation of Azo Dye Comparison of Photocatalytic Efficiency of $\mathrm{ZnO}$ and $\mathrm{TiO}_{2}$, Solar Energy Materialand Solar Cell., 77:65-82.

Singh, S. 2009. Electrical Transport and Optical Studies of Transition Metal Ion Doped ZnO and Synthesis of ZnO based Nanostructure by Chemical Route, Thermal Evaporation and Pulsed Laser Deposition, Thesis, Departmen Of Physics Indian, Institute Of Technology Madras.

Wardhana, W. A., 2004, Dampak Pencemaran Lingkungan, Cetakan keempat, Penerbit ANDI, Yogyakarta.

Wróbel, D., A. Boguta, R.M., 2001, Ion, Mixtures of synthetic organic dyes in a photoelectrochemical cell, J. Photochem. Photobiol. A Chem., 138 (1):7-22. 